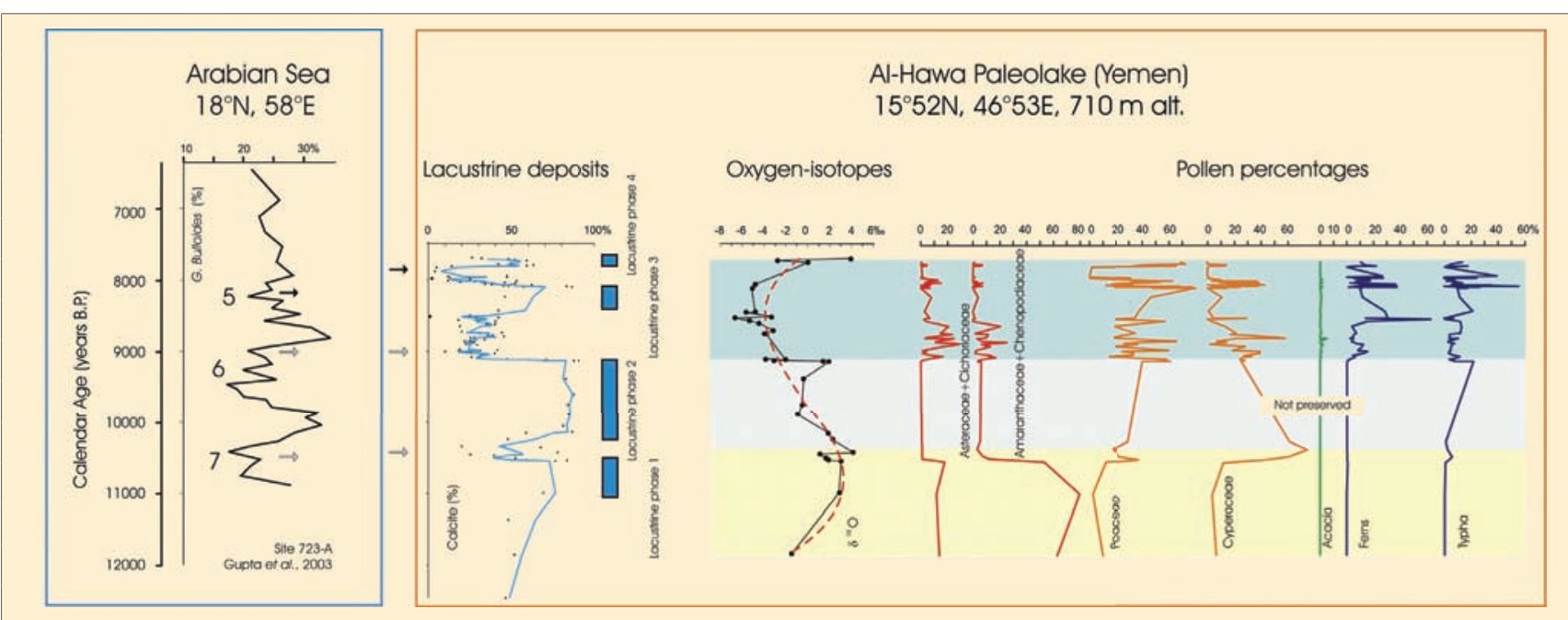

Figure 2: The "Arabian Humid Period" from marine and continental archives. Left panel: Globigerina bulloides percentages from ODP site 723 (Gupta et al., 2003) with highest percentages reflecting phases of strong upwelling in the Arabian sea. Numbers refer to Bond events (Bond et al., 1997). Right panel: the lacustrine record of al-Hawa (Yemen) with three "dry" events punctuating the humid period (arrows). Pollen data and the oxygen-isotope record on fresh-water shells shows the dramatic increase in summer monsoon rains from 9000 yrs B.P. onwards. Arid, evaporated, conditions increased toward the end of the "Arabian Humid Period," and the al-Hawa lake completely dried out at 7500 yrs B.P.

gest that the ITCZ reached the core site $\left(16^{\circ} \mathrm{N}\right)$ from $9 \mathrm{ka}$ BP onwards. In addition, the abrupt climate variations recorded from ice and ocean cores during the Holocene (Bond et al., 1997) have also been recorded in Southern Arabia, by a succession of dry phases, between 10.5-10.1, 9.18.4, and 8-7.8 ka BP, thus confirming previous observations on the Indian monsoon system from the adjacent ocean (Gupta et al., 2003).

\section{Conclusion}

The al-Hawa sedimentary sequence provides an exceptional, and rare, continuous record of environment and climate variations in the Southern Arabian Desert. Paleolake records are surprisingly scarce in this region (Lézine et al., in press). Al-Hawa, as with many of the other freshwater extensions in the Rub al'Khali desert, benefited from surficial runoff from the adjacent highlands located to the south (the Hadramawt plateaus) and to the west (the Yemen highlands). The flat morphology of its wide basin made it very sensitive to low amplitude variations in rainfall. The presence of the Hadramawt plateaus and the Yemen highlands, which acted as topographical and ecological barriers against the northward penetration of tropical plants (as observed in the Saharan desert at that time), played a determinant role in the vegetation composition, which remained of desert, semi-desert type throughout the Holocene humid period.

\section{Note}

The presented data is available in the MEDIAS database at: medias.obs-mip.fr/eclipse

\section{REFERENCES}

Bond, G., Showers, W., Cheseby, M., Lotti, R., Almasi, P., deMenocal, P., Priore, P., Cullen, H., Hajdas, I., and Bonani, G., 1997: A Pervasive Millennial-Scale Cycle in North Atlantic Holocene and Glacial Climates. Science, 278: 1257-1266.

Fleitman, D., Burns, S.J., Mudelsee, M., Neff, U., Kramers, J., Mangini, A., and Matter, A., 2003: Holocene forcing of the Indian monsoon recorded in a stalagmite from Southern Oman. Science, $\mathbf{3 0 0}$ 1737-1739

Gupta, A.K., Anderson, D.M., and Overpeck, J.T., 2003: Abrupt changes in the Asian Southwest monsoon during the Holocene and their links to the North Atlantic Ocean. Nature, 421: 354-357.

Lézine, A.-M., Saliège, J.-F., Robert, C., Werthz, F., and Inizan, M.-L. 1998: Holocene lakes from Ramlat-as Sab'atayn (Yemen) illustrate the impact of monsoon activity in Southern Arabia. Quaternary Research, 50: 290-299

Lézine A.-M., Tiercelin J.-J., Robert C., Saliège J.-F., Cleuziou S., Braemer F., and Inizan M.-L., in press: Centennial to millennial-scale variability of the Indian monsoon during the early Holocene from a sediment, pollen and isotope record from the desert of Yemen. Palaeogeography, Palaeoecology, Palaeoclimatology.

\title{
A better climate for human evolution
}

\section{Martin H. Trauth ${ }^{1}$, Mark A. Maslin ${ }^{2}$, Alan Deino ${ }^{3}$ and Manfred R. Strecker ${ }^{1}$}

'Department of Geosciences, University of Potsdam, Germany; trauth@geo.uni-potsdam.de ¿Environmental Change Research Center, University College London, UK

BBerkeley Geochronology Center, USA

Investigations of both terrestrial and marine paleoclimate archives have resulted in an ongoing debate concerning global vs. local climate forcing and associated environmental changes in East Africa. A better knowledge of shifts between dry and humid conditions is key to our understanding of processes influencing mammalian and, in particular, hominin evolution (deMenocal, 1995; Trauth et al., 2003, 2005). Because of the unique tectonic and magmatic evolution of the East African Rift System (EARS) and resulting changes in orography and drainage patterns, terrestrial paleoclimate records from these environments may not always automatically reflect the en- vironmental changes inferred from marine records. For example, the tectonic and magmatic evolution of the EARS has resulted in highly variable sedimentary environments in close proximity to each other, whose depositional record may be fundamentally influenced by local conditions rather than global signals. Thus, it is important to strive 


\section{Science Highlights: Open Section}

for a better understanding of riftrelated processes and indicators of regional climate change, with the aim of characterizing hydrological changes in East Africa and, ultimately, of comparing them to global processes.

\section{History of the East African rift lakes}

The EARS is characterized by a southward propagation of rifting, including the formation of major faults, subsequent densification and tectonic differentiation of extensional basins and coeval magmatic activity. The earliest formation of lake basins in the northern parts of the rift is an integral part of these processes. In the Ethiopian Rift, volcanism started between 45 and 33 $\mathrm{Ma}$, in northern Kenya at around 33 $\mathrm{Ma}$, and continued to about $25 \mathrm{Ma}$, whereas the magmatic activity of the central and southern segments of the rift in Kenya and Tanzania started between 15 and $8 \mathrm{Ma}$. Major faulting in Ethiopia between 20 to $14 \mathrm{Ma}$ was followed by the generation of major east-dipping faults in northern Kenya between 12 and 7 Ma, superseded by normal faulting on the western side of the Central

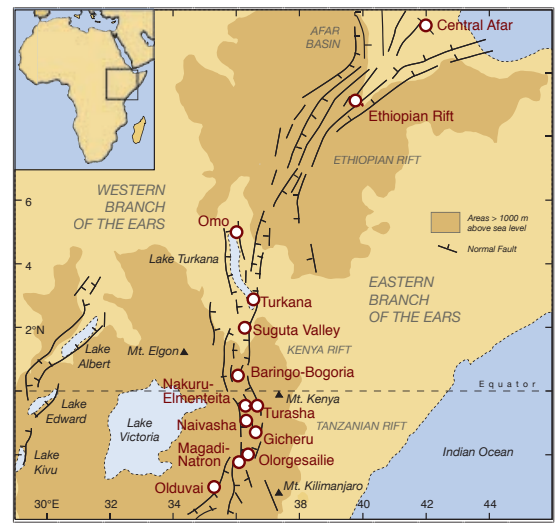

Figure 1: Map of East Africa showing topography, faults and lake basins.

and Southern Kenya Rift between 9 and $6 \mathrm{Ma}$. These early halfgraben formed during approx. E-W oriented extension and were subsequently faulted antithetically between about 5.5 and 3.7 $\mathrm{Ma}$, which generated a full-graben morphology. Major normal faulting in the Magadi-Natron and Olduvai basins occurred at 1.2 $\mathrm{Ma}$ and produced the present-day rift escarpments (Tiercelin and Lezzar, 2002).

The southward propagation of extensional processes in the EARS is also reflected in the earliest formation of lake basins in East Africa. The fluvio-lacustrine history of the Afar, Omo-Turkana and Baringo-
Bogoria basins in the north started in the Middle and Upper Miocene, whereas the age of the oldest lacustrine sequences in the central and southern segments of the rift (i.e., Kenya and Tanzania) is Early Pliocene (Tiercelin and Lezzar, 2002). However, if tectonics were the sole control over the appearance and disappearance of lakes, then either a N-S or NW-SE temporal pattern would be expected. In contrast, what is observed is the appearance of large, deep lakes synchronous across a large geographical area at 2.7-2.5 Ma, 1.9-1.7 $\mathrm{Ma}$ and 1.1-0.9 Ma (Trauth et al., 2005), suggesting regional climatic control. For the reconstruction of these lakes, we sampled several tens of meters thick lacustrine sequences at meter to half-meter intervals. The diatomite and pyroclastic material-bearing sediments were investigated for sediment characteristics, authigenic minerals, and diatom flora. Where possible, these units were radiometrically dated using anorthoclase and sanidine phenocryst concentrates from several tuff beds and lava flows.

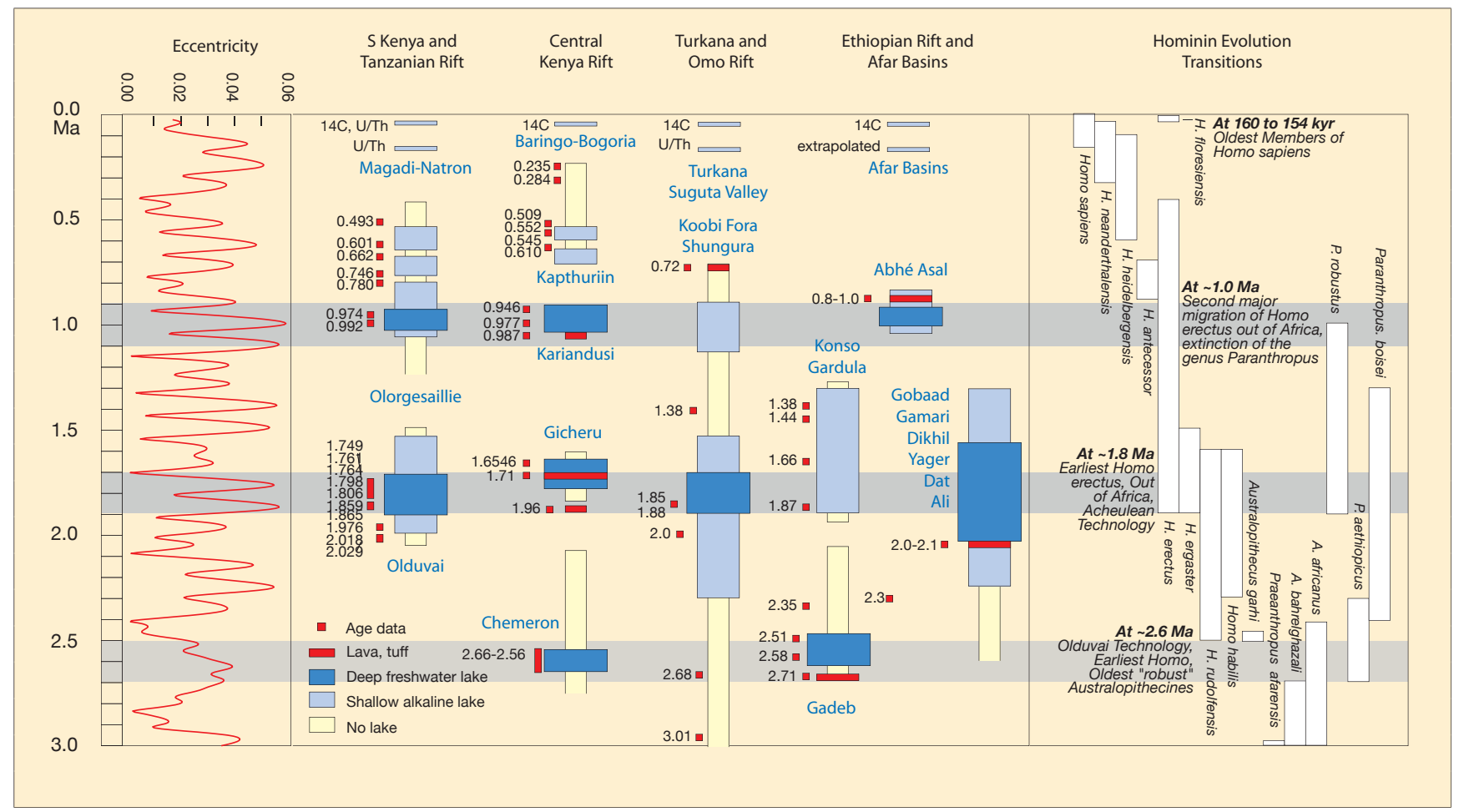

Figure 2: Insolation variation, wet periods in East Africa and human evolution. The compilation of lake records is based on a large volume of literature (Olduvai, Magadi-Natron-Olgesailie, Baringo-Bogoria, Omo-Turkana-Suguta, Ethiopian Rift and Afar), as well as from our own work (Central Kenya Rift) (see Trauth et al. (2005) and references therein for details). 


\section{Paleoclimatic implications}

The alternating wet and dry phases during the last $3 \mathrm{Ma}$ correlate with numerous other humidity paleoclimate indicators in East Africa, such as mammal assemblages, fossil forest leaves, wood and pollen, as well as with Mediterranean sapropels and dust. The most fascinating phenomenon in this context is the anti-correlation between the East African lake levels and paleoclimate records from subtropical West and Northeast Africa (deMenocal, 1995). In this context, it has been proposed that eolian dust in ocean sediment cores off western and eastern subtropical Africa record environmental changes in Africa that were also thought to represent drier conditions in regions that we studied. However, records from sediment cores off West Africa and Oman may not automatically reflect the nature of East African climate change, since the source areas of these terrigenous deposits are in the Sahara/Sahel regions off West Africa, Arabian peninsula (more than $80 \%$ ) and northeast Africa (less than 20\%), rather than equatorial East Africa where the hominins evolved.

Importantly, the periods of increased humidity, as reconstructed from East African lake levels, correlate both with significant global climatic changes, as well as periods of maximum eccentricity. The period between 2.7 and 2.5 Ma corresponds to the onset of Northern Hemisphere Glaciation, the period between 1.9 and 1.7 Ma corresponds to a significant shift in the Walker Circulation, and the interval between 1.0 and $0.8 \mathrm{Ma}$ corresponds to the initiation of the Mid-Pleistocene Revolution. The phases of high lakelevels in the Ethiopian and Kenyan rifts also correlate with periods of maximum eccentricity, suggesting that changes in local solar radiation are equally important in the moisture history on longer time scales. Since the main effect of eccentricity is to modulate the amplitude of Earth's precession cycles, at times of maximum eccentricity, the seasonality in insolation and, hence, the intensity of the rainy seasons in the tropics increases (Clement et al., 2004). The combination of significant global climate changes with maxima in precessional amplitudes may explain why these humid periods recur only after $0.4 \mathrm{Ma}$, whereas maximum eccentricity and, hence, maximum amplitudes in precession occur at higher periodicities.

These periods of extreme climate variability coincide with key periods of speciation and dispersal of mammals and hominins in East Africa and may have been the cat- alyst for human evolution. In this respect, the close link between lacustrine environments and sites of early hominin occupation is intriguing. Based on these observations, we identify two important issues in mammalian and hominin evolution in East Africa. First, sustained periods of amenable climatic and environmental conditions lasting for protracted periods on the order of $10^{4}-10^{5}$ years, promoting synpatric evolution. Second, lakes may have rapidly appeared and disappeared with precessional cyclicities, producing a rapidly changing mosaic of environments, which ultimately helped promote allopatric evolution.

\footnotetext{
REFERENCES

Clement, A.C., Hall., A. and Broccoli, A.J., 2004: The importance of precessional signals in the tropical climate. Climate Dynamics, 22: 327-341.

deMenocal, P., 1995: Plio-Pleistocene African Climate. Science, 270: 53-59.

Tiercelin, J.J., and Lezzar, K.E., 2002: A 300 million years history of rift lakes in Central and East Africa: an updated broad review. In: Odada, E.O., Olago, D.O. (Eds.), The East African great lakes: limnology, paleolimnology and biodiversity, Kluwer, Dordrecht, pp. 3-60.

Trauth, M.H., Deino, A., Bergner, A.G.N., and Strecker, M.R., 2003: East African climate change and orbital forcing during the last $175 \mathrm{kyr}$ BP. Earth and Planetary Science Letters, 206: 297-313.

Trauth, M.H., Maslin, M.A., Deino, A., and Strecker, M.R., 2005: Late Cenozoic Moisture History of East Africa. Science, 309: 2051-2053.
}

\title{
Surface temperature reconstructions for the last 2000 years
}

\author{
Gerald R. NoRth ${ }^{1}$ and Ian Kraucunas ${ }^{2}$ \\ on behalf of the Committee on Surface Temperature Reconstructions for the Last 2,000 Years, U.S. National Research Council* \\ ${ }^{1}$ Department of Atmospheric Sciences, Texas A\&M University, College Station, USA; g-north@tamu.edu \\ ²Board on Atmospheric Sciences and Climate, National Research Council, Washington, USA; ikraucunas@nas.edu
}

In response to a request from the U.S. Congress, the U.S. National Research Council (NRC) assembled a committee to describe and assess scientific efforts to reconstruct surface temperature records for the Earth over the last 2000 years. This research, and especially the reconstructions originally published by Mann et al. (1998, 1999) and featured in the Intergovernmental Panel on Climate Change
Third Assessment Report (2001), attracted considerable attention because the authors concluded that the Northern Hemisphere was likely warmer during the late 20th century than at any other time during the past millennium. Controversy arose because many people interpreted this result as definitive evidence of anthropogenic causes of recent climate change, while others criticized the methodolo- gies and data that were used. The NRC committee's report (2006) attempts to diffuse this controversy by providing a comprehensive assessment of surface temperature reconstructions for the last 2000 years, as well as the implications of these efforts for our understanding of global climate change. 